\title{
PODPORZĄDKOWANI JUTRA. CHORWACKA PROZA DYSTOPIJNA W UJĘCIU POSTKOLONIALNYM
}

\author{
AleKSANDRA WojTASZEK ${ }^{1}$ \\ (Uniwersytet Jagielloński, Kraków)
}

\begin{abstract}
Słowa kluczowe: dystopia, perspektywa postkolonialna, literatura chorwacka, wykluczenie, podporządkowanie

Key words: dystopia, postcolonial perspective, Croatian literature, exclusion, subordination
\end{abstract}

\begin{abstract}
Abstrakt: Aleksandra Wojtaszek, PODPORZĄDKOWANI JUTRA. CHORWACKA PROZA DYSTOPIJNA W UJĘCIU POSTKOLONIALNYM. „PORÓWNANIA” 19, 2016. T. XIX. S. 150-162. ISSN 1733-165X. W literaturze chorwackiej, która od czasu rozpadu Jugosławii zdominowana była głównie przez tendencje neorealistyczne, na przestrzeni kilku ostatnich lat zaobserwować można gwałtowny rozkwit popularności dotychczas prawie nieobecnej dystopii. Zakres środków, którymi posługuje się fantastyka, umożliwia prezentację negatywnych tendencji współczesności na poziomie systemowym, bez konieczności przedstawienia jej poszczególnych epifenomenów. Narzędzi metodologicznych do analizy zaprezentowanych w niniejszym artykule utworów dostarcza refleksja postkolonialna, zaś kluczowymi narzędziami operacyjnymi w proponowanej interpretacji chorwackiej prozy dystopijnej są kategorie wykluczenia, podporządkowania i władzy, zaczerpnięte przede wszystkim z filozofii Michela Foucaulta oraz z prac kontynuatora jego myśli - Giorgio Agambena, a także kwestie relacji i głębokich podziałów pomiędzy centrum a peryferiami, przemocy epistemicznej oraz dyskursu postkolonialnego.
\end{abstract}

Abstract: Aleksandra Wojtaszek, THE SUBORDINATED OF TOMORROW. CROATIAN DYSTOPIAN PROSE IN THE POSTCOLONIAL APPROACH. "PORÓWNANIA" 19, 2016. Vol. XIX. P. 150-162. ISSN 1733-165X. In the Croatian literature, which since the collapse of Yugoslavia has been dominated mainly by neo-realistic trends, over the past few years the rapid growth of popularity of dystopia - a genre which until now almost did not occur - can be observed. The means used in the work of fiction allow for representation of the present-day negative trends at the system level, without the need to present individual epiphenomena. Methodological tools, used for the analysis of the literature presented in this article, are provided by the postcolonial reflection, and the key operational tools used in the proposed interpretation of the Croatian

1 E-mail: aleksandrawojtaszek@onet.eu 
dystopian fiction are categories of exclusion, subordination and authority, derived directly from the philosophy of Michel Foucault and the works of his continuator - Giorgio Agamben, as well as the issues connected to the relations and deep divisions between the center and the peripheries, the epistemic violence and the post-colonial discourse.

Utwory dystopijne dostarczają wielu argumentów potwierdzających tezę, że sztafaż środków wyrazu przysługujących fantastyce umożliwia twórcom o wiele bardziej wyrazistą prezentację problemów współczesności i wyzwań stojących przed nią niż ma to miejsce w przypadku literatury mimetycznej, zgodnie z myślą Frederica Jamesona: „właściwe dla science-fiction narzędzia przedstawiania [...] przekazują bardziej wiarygodną informację o współczesnym świecie niż wyjałowiony realizm" (Jameson 2011: 251). Potencjał epistemiczny fantastyki podkreśla także Jerzy Jarzębski w tekście Realizm podszyty fantastyka poświęconym najnowszej polskiej prozie: „Do fantastyki odwołujemy się po to, aby zrozumieć kształt naszego własnego życia i rządzący nim system wartości" (Jarzębski 51). Chociaż zastosowanie metodologii postkolonialnej do interpretacji tekstów opisujących fikcyjne, futurologiczne wizje systemów i społeczeństw może budzić pewne wątpliwości, to jednak okazuje się, że problematyka relacji między centrum a peryferiami, wpływu władzy na kształtowanie kultur i dyskursów, a także zagadnienie dominacji i podporządkowania, mechanizmów władzy i oporu wobec niej są niezwykle przydatne $w$ analizie $i$ interpretacji dystopii - utworów, które według Lymana Towera Sargenta prezentują „nieistniejące społeczeństwo, opisane ze znaczącą dbałością o szczegóły i zwykle osadzone gdzieś w czasie i przestrzeni, które autor stara się ukazać współczesnemu mu czytelnikowi jako znacznie gorsze niż społeczeństwo, w jakim ten czytelnik ży$\mathrm{je}^{\prime \prime 2}$ (Sargent 9).

Dystopia, co szczególnie dobrze widoczne na przedstawionych w niniejszym tekście przykładach z literatury chorwackiej, wydobywa problem przejawów nowych, neokolonialnych form podporządkowania, wywołanych ekspansją kapitalizmu i procesami globalizacji, oraz opisuje współczesne wcielenia neoimperialnych form władzy. Ewa Domańska, nawiązując do definicji stworzonej przez Vijaya Mishrę i Boba Hodge'a w tekście What is Post(-)Colonialism?, pisze o perspektywie postkolonialnej, odnajdującejzastosowanie „wszędzietam, gdzie istnieją stosunkipodporządkowania i dominacji narzucane przez imperialne struktury władzy" (Domańska 158), a zatem niezwykle użytecznej do analizy systemów i społeczeństw opisanych w dystopiach.

Zgodnie z klasyfikacją Andrzeja Zgorzelskiego, który oparł się na rozważaniach Darka Suvina - kanadyjskiego badacza pochodzenia chorwackiego - dystopia zalicza się, obok science-fiction czy fantasy, do literatury egzomimetycznej, która

2, , $[. .$.$] A non-existent society described in considerable detail and normally located in time and space$ that the author intended a contemporaneous reader to view as considerably worse than the society in which that reader lived".

Tu i później, jeśli nie podano inaczej, tłum. A. Wojtaszek. 
zakładając językową kompetencję odbiorcy określającą jego wiedzę o porządku empirii - presuponuje spekulatywne rozważania nad innymi możliwymi modelami rzeczywistości, tworząc je albo poprzez operowanie wizją i marzeniami, lub też przez racjonalną ekstrapolację i analogię (Zgorzelski 96).

W przypadku dystopii ten alternatywny model pozostaje jednak $\mathrm{w}$ ścisłym związku z empiryczną rzeczywistością doświadczaną przez autora i czytelników, co wyraźnie widać w definicji zaprezentowanej przez Sargenta - w utworach dystopijnych pojawiają się częste odwołania do rzeczywistości, a prezentowane w nich wizje czerpią z tendencji wywiedzionych z teraźniejszości. Antyutopia z kolei wyprowadza negatywne wizje przyszłej egzystencji człowieka z przesłanek utopijnych, parodiuje utopie, przejaskrawia je i polemizuje z zawartymi w nich koncepcjami, zaś dystopia staje się „kompromitacją rzeczywistości $\mathrm{w}$ imię jakiegoś nie ujawnionego bezpośrednio ideału" (Szacki 203). Kluczową funkcją utworów dystopijnych jest zatem unaocznienie niebezpiecznych tendencji występujących w społeczeństwie, często jeszcze nieobecnych w świadomości czytelników, oraz skłonienie do refleksji nad osiągnięciami cywilizacji i nad drogami, którymi ona podąża.

W dwudziestowiecznej literaturze chorwackiej zaledwie kilka powieści spełnia wymogi gatunkowe dystopii ${ }^{3}$, zaś początek XXI wieku przyniósł rozkwit prozy utrzymanej w tym, dotychczas marginalnym, nurcie: w 2003 roku ukazała się powieść uznanego dramaturga, Iva Brešana, pod tytułem Država Božja 2053., będąca, jak zadeklarował sam autor, reakcją na rosnący wpływ Kościoła katolickiego na politykę Chorwacji (Brešan 2013). Cztery lata później Danilo Brozović, autor kilku opowiadań dystopijnych, wydał powieść Bojno polje Istra (2007) tematyzującą rozgrywającą się w przyszłości wojnę o niepodległość Istrii. Prawdziwy boom nastąpił jednak po 2010 roku - na rynku wydawniczym pojawiły się m.in. intermedialna powieść o zombie atakujących Zagrzeb autorstwa Marka Mihalinca i Velimira Grgicia (Kriza. Hrvatski horor, 2010), a także Irbis Aleksandra Žiljaka (2012), Planet Friedman Josipa Mlakicia (2012), Lomljenje vjetra (2011) i Mjesečev meridijan (2015) Eda Popovicia, 2084. Kuća velikog jada (2012) i Vladmir se vraća kući (2014) Ivo Balenovicia, Rat za peti okus (2015) i Eliksir istine (2016) Veljka Barbieriego oraz zbiór opowiadań Nova Država Hrvatija 2033. (2014) autorstwa grupy pisarzy z Rijeki, ukazujących Chorwację przyszłości w szponach klerofaszystowskiej prawicy. Niewątpliwie zjawisko to nie pozostaje bez związku z tendencjami globalnymi - Jamesonowskie impulsy dystopijne zdają się coraz powszechniej przenikać rozmaite dyskursy kultury popularnej, czego przykłady widoczne są chociażby w kinematografii ostatnich lat czy niezwykłej popularności gatunku young adult dystopia.

3 Na tej krótkiej liście znajdują się takie utwory jak Na Pacifiku godine 2255. Milana Šufflaya (1922), Pronalazak Athanatika Vladana Desnicy (1957), Trojanski konj (1980) i Epitaf carskog gurmana (1983) Veljka Barbieri oraz Utov dnevnik Branka Belana (1982) z zastrzeżeniem, że w przypadku pierwszego utworu mowa raczej o mieszaniu elementów utopijnych, antyutopijnych i dystopijnych. 
W przypadku Chorwacji fenomen ten zasługuje jednak na szczególną uwagę nie tylko ze względu na wspomnianą nieobecność tradycji dystopijnej, ale także w kontekście zmiany opartego na wzorcach neorealistycznych modelu literackiego, który dominował w tamtejszej literaturze od 1991 roku. Nurt ten doczekał się rozmaitych nazw, jednak do tej pory najbardziej upowszechniły się stvarnosna pro$z a$ (proza rzeczywistościowa) (Pogačnik 2006) i kritički mimetizam (mimetyzm krytyczny) (Bagić 2007), przy czym zauważyć należy, że terminami tymi obejmowano utwory o dużym zróżnicowaniu zarówno tematycznym, jak i formalnym. Jak pisze Krešimir Bagić, pojęcie „rzeczywistości” stało się dla chorwackich krytyków swoistym „wytrychem" - zazwyczaj używanym bez doprecyzowania, czy miałoby się odnosić do warstwy stylistycznej, struktury i retoryki tekstu, czy też do specyficznej tematyki lub polityki literackiej (Bagić 2016). Głównych czynników odpowiedzialnych za dominację neorealizmu jako stereoty powo najbardziej wiarygodnej techniki przekazu brutalnej życiowej „prawdy” upatrywać należy w uwarunkowaniach pozaliterackich - szczególnie w latach dziewięćdziesiątych wśród autorów i krytyków rozpowszechnione było przekonanie, że poetyki odbiegające od reprezentacji mimetycznych zdradzają tendencje eskapistyczne i nie są adekwatnym narzędziem do przedstawiania dokonujących się przemian, związanych przede wszystkim z wojną i rozpadem Jugosławii oraz transformacją ustrojową i społeczną, co najbardziej eksplicytnie wyraził w swoim eseju Jurica Pavičić:

Literatura traktująca o literaturze i szukająca rozrywki w gabinecie luster literackich kodów i intertekstów, staje się nagle potwornie niesympatyczna dla czytelnika, który okłada dom workami z piaskiem, a okna zakleja brązową taśmą klejącą [...]. W delirycznej rzeczywistości nikt, ani z lewej, ani prawej strony, nie miał już ochoty na wymyślone, fikcjonalne przestrzenie. Sumatry i Jawy [metonimia literatury postmodernistycznej lat osiemdziesiątych - przyp. A.W.] z dnia na dzień otrzymały wizę wyjazdową z odmętów gustu literackiego (Pavičić 2004).

Nie znaczy to, że literatura fantastyczna, również ta utrzymana w konwencji egzomimetycznej, a zatem tradycyjnie łączona $z$ takimi gatunkami jak science-fiction czy fantasy, nie powstawała od lat dziewięćdziesiątych XX wieku (przykładem niech będzie chociażby nieprzerwana od ponad czterdziestu lat działalność zagrzebskiego Towarzystwa Fantastyki Naukowej SFera, corocznie wydającego antologie), jednak zajmowała ona miejsce na obrzeżach sceny literackiej, nie budząc szczególnego zainteresowania krytyków i docierając głównie do wąskiej grupy czytelników: „sporadyczne almanachy i zbiory opowiadań SF wychodzące spod pióra miejscowych entuzjastów tego gatunku pozostają na subkulturowym marginesie i nie są uznawane za relewantną składową korpusu literatury narodowej, ani do niego włączane" (Gajin 44).

Wyczerpująca analiza przyczyn nagłego wzrostu popularności dystopii przekracza możliwości niniejszego szkicu, należy jednak zauważyć, że nie jest on na- 
stępstwem rewolucji, zmiany pokoleniowej czy całkowitej reorientacji dotychczasowego paradygmatu literackiego, ale raczej wynika z ewolucji obowiązującego modelu. Już w 2004 roku Jagna Pogačnik w symptomatycznie zatytułowanym tekście Gdje je nestala utopija? (Gdzie zniknęła utopia?) zauważyła, że literaturę utopijną łączy z ówczesną chorwacką produkcją prozatorską krytyka istniejących stosunków społecznych i pragnienie ich zmiany. Autorka postrzegała przy tym utopijność w literaturze jako „,krok naprzód po oczyszczeniu terenu”, trafnie przewidując nadchodzący wzrost zainteresowania taką formą wypowiedzi o rzeczywistości i (już nie tak trafnie) łącząc go przede wszystkim ze zmianą pokoleniową na chorwackiej scenie literackiej (Pogačnik 2004).

W niniejszym tekście nie jest możliwe wyczerpujące zdiagnozowanie przyczyn nagłego wzrostu popularności dystopii, należy jednak zauważyć, że nie jest on następstwem rewolucji, zmiany pokoleniowej czy całkowitej reorientacji dotychczasowego paradygmatu literackiego, ale raczej ewolucji obowiązującego modelu. We wskazanych przeze mnie powieściach dystopijnych i w chorwackiej prozie neorealistycznej uwidacznia się krytyczne podejście do obserwowanej rzeczywistości ich autorzy sondują podobne aberracje społeczne i wyrażają wobec nich swoją dezaprobatę, jednak jak zauważa Boris Postnikov, dystopia, w odróżnieniu od krytycznego mimetyzmu, skupionego na wiernym i szczegółowym odtwarzaniu rzeczywistości empirycznej, umożliwia konceptualizację systemowych uwarunkowań poszczególnych bolączek chorwackiego życia społecznego, ewoluuje zatem od krytyki pojedynczych zjawisk w stronę krytyki postrzeganego całościowo systemu (Postnikov 2013).

Igor Gajin zauważa z kolei zbieżność tematyczną utworów dystopijnych, które koncentrują się wokół zjawisk wywołanych dominacją neoliberalnego kapitalizmu i globalizacją. Badacz podkreśla przy tym, że - w odróżnieniu od dominującej w latach siedemdziesiątych na chorwackiej scenie literackiej generacji twórców określanych mianem fantastičari lub borhesovci - autorów najnowszych dzieł nie interesują typowe dla postmodernistycznych poetyk kwestie, takie jak relacja rzeczywistości i fikcji, problem autonomiczności tekstu czy dekonstruowanie jego złudnej autentyczności, ale poprzez swoje wizje przyszłości dążą oni do pełnej, holistycznej interpretacji współczesności, problematyzują różnorodne alternatywy dla bieżących problemów, posługując się przy tym hiperbolizacją, parabolą, hipotetyczną radykalizacją i karykaturą (Gajin 42-44).

Wbrew przewidywaniom Pogačnik twórcami najnowszych powieści dystopijnych nie są pisarze młodszego pokolenia, ale autorzy o ugruntowanej pozycji, przynależący do głównego nurtu chorwackiego życia literackiego, jak chociażby urodzony w 1964 roku Chorwat z Bośni, Josip Mlakić, czy Edo Popović (urodzony w $1957 \mathrm{roku}$ ), obecny na chorwackiej scenie literackiej od lat osiemdziesiątych (jego debiutancki zbiór opowiadań Ponoćni Boogie jest w Chorwacji uważany za kultowy), którzy dotychczasową twórczością wpisywali się w dominujący, neore- 
alistyczny model prezentowania negatywnych skutków wojny czy transformacji ustrojowej. Jedynie Aleksandar Žiljak na stałe związany jest z chorwacką sceną fantastyczną, za swoją twórczość otrzymał dwukrotnie nagrodę SFERA przyznawaną przez zagrzebskie Towarzystwo Fantastyki Naukowej, zredagował także wspólnie z Tomislavem Šakiciem antologię chorwackiej fantastyki naukowej z lat 1976-2006 (pod tytułem Ad Astra).

Charakterystyczna dla dystopii jako gatunku jest potrzeba szczegółowej prezentacji stworzonego $\mathrm{w}$ utworze systemu - fabuła, nieco bardziej rozbudowana niż w utopiach pozytywnych, ma jednak drugorzędne znaczenie. Zarówno w utopiach pozytywnych, jak $\mathrm{i} \mathrm{w}$ negatywnych widoczne są pewne niezmienne elementy budowy świata przedstawionego - jednym z nich jest szczątkowa fabuła, zredukowana na rzecz "maksymalnie unaoczniającej prezentacji obrazu świata” (Juszczyk 23). Konstrukcja fabuły w dystopii oparta jest na schemacie przypominającym zasady rządzące melodramatem - stałym elementem jest na przykład motyw spotkania przez bohatera osoby pozostającej z nim w relacji miłosnej lub przyjacielskiej, dzięki której uświadamia on sobie dystopijność otaczającego go świata (Juszczyk 103). Najbardziej wyraziście w ten schemat wpisuje się Planet Friedman - przynależący do elity lekarz Gerhard przechodzi przemianę ze względu na relację z pacjentką, niepokorną sportsmenką Paulą, która dzięki swoim osiągnięciom może wieść dostatnie życie, jednak wychowana wśród wykluczonych ekonomicznie i społecznie, nie potrafi wyzbyć się wyrzutów sumienia i niechęci do zamieszkiwanego przez siebie świata złudnego luksusu. Bohater dystopii doświadcza, zazwyczaj pierwszego, spotkania z Innym: bliską osobą, która jednak, występując $z$ radykalnie odmiennych pozycji ideologicznych, odkrywa przed nim niedostatki i wady systemu, w którym do tej pory żył, nieświadomy sprawowanej nad nim dyskursywnej przemocy. Dystopia niejako a priori prezentuje subiektywne spojrzenie podporządkowanego, skolonizowanego podmiotu.

Aby czytelnik mógł odczytać wykreowany w utworze system jako dystopijny, zazwyczaj niezbędny jest bohater o równie negatywnym nastawieniu, znajdujący się $\mathrm{w}$ pozycji zdominowanego podmiotu, który jednak poprzez uświadomienie sobie swojego położenia dokonuje pierwszego aktu symbolicznego oporu wobec władzy i systemu - subaltern, jako „podporządkowany Inny”, w dystopii zyskuje głos i poniekąd zmusza czytelnika do wysłuchania swoich racji. Utopia jednych staje się dystopią innych - radykalnie negatywny porządek społeczny jest $\mathrm{w}$ dystopii przedstawiony ,z punktu widzenia oraz w ramach systemu wartości niezadowolonej klasy społecznej lub zbioru klas, tak jak reprodukuje je pisarz" ${ }^{4}$ (Suvin 188).

Fundamentalny dla istnienia i trwania opisanego $w$ analizowanych powieściach dystopijnego porządku jest podział przedstawionego w nich świata na wyraźnie

4 "From the point of view and within the value-system of a discontented social class or congeries of classes, as refracted through the writer". 
oddzielne przestrzenie, w których żyją z jednej strony uprzywilejowani, z drugiej zaś wykluczeni. U Mlakicia cała planeta podzielona jest na strefy: podczas gdy obywatele mieszkający w zonie A żyją w dostatku i względnej szczęśliwości, mieszkańcy strefy B umierają z głodu i nędzy, wyniszczani łatwo uleczalnymi chorobami, zona C jest zaś zapomnianym pustkowiem, na którym przetrwali nieliczni. Popović dzieli Chorwację na część pozostającą wewnątrz tzw. Holdingu, czyli największych miast otoczonych murem, gdzie żyją posiadacze dóbr, oraz na pozostałe tereny, wyrzucone poza obręb kontroli miejsce życia dla wyrzutków i odpady kapitalistycznego systemu nazywane Zona. Žiljak zaś wokół miast buduje ogromne wieże, w których najbogatsi schronili się przed władającą wokół entropią i przemocą, ziemią niczyją, gdzie władzę przejęły organizacje mafijne i terrorystyczne. Imperialne ośrodki mocy i władzy także geograficznie odizolowane są od peryferiów dzięki murom, wieżom czy laserowym skanerom.

Opisywany niegdyś w dystopiach świat całkowitego nadzoru został zastąpiony przez uniwersum głębokiego podziału - władza rezygnuje z pokusy całkowitej kontroli i wycofuje się ze stref zamieszkanych przez odrzuconych, świadomie ogranicza moc swojego prawa tylko do najbardziej interesującej ją części globu, a pozostałe pozostawia praktycznie bez kontroli. Giorgio Agamben twierdzi, że tym, co prawdziwie umacnia i konstytuuje władzę, jest jej moc stwarzania wyjątków, wewnątrz których prawo nie obowiązuje - stanów wyjątkowych. Dzięki temu procesowi „włączającego wyłączenia” norma może w pełni funkcjonować (Agamben 30). Jeśli więc wyjątek umacnia normę, a prawo konstytuuje ustanowienie miejsc, w których ono nie obowiązuje, tym, co prawdziwie podkreśla porządek stworzonych dystopii, są ich przeciwieństwa, strefy pozornego nieładu, w rzeczywistości zaś obszary, skąd świadomie wycofuje się prawo, skolonizowane i brutalnie eksploatowane, choć pozornie pozostawione bez kontroli. Analizując dokładnie przebieg formowania stref $\mathrm{w}$ powieści Mlakicia, budowania muru w dziele Popovicia czy wieży u Žiljaka, można dojść do wniosku, że u podstaw tych działań nie leży potrzeba ochrony potencjału i dóbr uprzywilejowanych, ale chęć wyrzucenia poza system tych elementów, które do niego nie pasują.

Mieszkańcy spoza uprzywilejowanej strefy stają się ucieleśnieniem figury homo sacer - ich życie jest czystą biologią, statystyką, mogą w każdej chwili zostać zabici, jeśli tylko zajdzie taka potrzeba, na przykład ekonomiczna. Włoski filozof przypomina o ryzyku związanym z przejęciem przez władzę zainteresowania biologicznym, „nagim” życiem obywateli i kompetencji decydowania o ustanawianiu stanów wyjątkowych, a zatem o życiu lub śmierci - wszystkim nam w każdej chwili grozi możliwość bycia pozbawionym bytu politycznego (bios) i powrotu do stanu nagiego, dysponowalnego życia (zoe). Najlepiej wiedzą o tym bohaterowie dystopii, żyjący w obawie, czy błędne posunięcie nie będzie skutkowało wygnaniem do tej „drugiej” przestrzeni, w której ich życie utraci polityczną wartość - na planecie Friedman, aby zostać wyrzutkiem, wystarczy spaść poniżej tzw. progu wypłacal- 
ności, w Holdingu zaś złamać jeden z niezliczonych zakazów, chociażby spania $\mathrm{w}$ miejscu publicznym czy rekreacji na wolnym powietrzu. Po zewnętrznej stronie murów włada zaś bezprawie, prawo silniejszego i przemoc, która sankcjonuje władzę zdolną dokonać takiego rozdziału.

Podział na centra i peryferie (czy też metropolie i satelity) spowodowany jest przede wszystkim nierównomiernym rozwojem kapitalizmu, który sprawia, że satelity stają się uzależnione od metropolii, te zaś czerpią z wyzysku skolonizowanych, narzucając im przy tym swój dyskurs i pozbawiając ich środków niezbędnych do wytworzenia własnych kategorii, a więc także do uzyskania określonego poziomu świadomości, pozwalającego na wyrwanie się z okowów przemocy epistemicznej. W powieści Irbis główny bohater wprost stwierdza, że centra mocy znajdujące się w wieżach celowo utrzymują pozostałą część świata w stanie entropii, dezinformacji i brutalnej przemocy, gdyż sprzyja to klasie panującej, małej grupie uprzywilejowanych, bogacących się i zyskujących dzięki temu władzę. Jedynym sposobem, aby zmienić zastany porządek, jest zatem całkowite zniszczenie takich miejsc.

Wbrew postawionej na początku tekstu tezie definiującej dystopię jako gatunek z założenia oddający głos podporządkowanym, należy zwrócić uwagę, że owi podporządkowani należą do specyficznej grupy jednostek, które uzyskały określony poziom świadomości pozwalający im uznać zastany świat za dystopijny i wyrazić swoją niezgodę na rzeczywistość. Zbuntowani przeciwko takiemu porządkowi wywodzą się zwykle z grup, czy należałoby raczej powiedzieć: z klas, uprzywilejowanych - uświadamiają sobie własne zniewolenie, któremu poddane są w opisanych systemach prawie wszystkie jednostki, ale tym, co sprawia, że zaczynają postrzegać porządek swojego świata jako radykalnie zły, jest kontakt z dramatycznymi nierównościami społecznymi, biedą i przemocą w strefach wykluc $\mathrm{A}$, w której do tej pory wiódł w miarę bezpieczny żywot, i odbywa podróż przez zony B i C (Mlakić wyraźnie nawiązuje do podziału na Pierwszy, Drugi i Trzeci Świat), odkrywając szokującą prawdę o rzeczywistości, w której wcześniej funkcjonował bez szczególnych rozterek moralnych. Podobnie bohaterowie Popovicia: Fraktalna, Vrtlar i Vanča samoistnie decydują się opuścić Holding i dołączyć do ruchu oporu działającego pod nazwą Nejestivi (Niejadalni) - każdy z nich jest silną osobowością i na poziomie symbolicznym prezentuje jedną z alternatywnych metod funkcjonowania w opisanym przez autora świecie: eskapizm, przemoc oraz świadomą współpracę z systemem. Także narrator i główny bohater Irbisa, były żołnierz, dzięki modyfikacjom genetycznym umieszczony $w$ ciele śnieżnej pantery, nie jest typowym biernym, podporządkowanym podmiotem - przy pomocy kłów i pazurów usiłuje wywalczyć sobie przetrwanie $\mathrm{w}$ świecie pełnym chaosu, przemocy i niesprawiedliwości. Śledząc perspektywy tych bohaterów, otrzymujemy relację na temat mechanizmów funkcjonowania dystopijnego świata - jednak ludzie wykluczeni, podwójnie podporządkowani, nieświadomi rządzących nimi sił i hegemonicznych dyskursów, po raz kolejny pozostają niemi: „Dla (płciowo nieokreślonej) grupy 
«prawdziwych» podporządkowanych innych, których tożsamością jest różnica, nie istnieje nieprzedstawialny podmiot podporządkowanych innych, który może znać siebie samego i mówić w swoim imieniu" (Spivak 213).

Obywatele stref uprzywilejowanych, poddani manipulacjom władzy, dzięki procesom dyskursywnego ubezwłasnowolnienia Innego i jego dehumanizacji traktują mieszkańców innych stref jako jednostki niższego rzędu, których życie nie zasługuje na ochronę, bowiem nie posiada obiektywnej wartości, mimo że podział na uprzywilejowanych i wykluczonych jest czysto arbitralny i związany jedynie z czynnikami ekonomicznymi czy też z przynależnością do określonej klasy społecznej. Dominantą dystopijnego świata staje się podział na te dwie grupy, który niweluje dotychczasowe różnice wyznaczane przez płeć, rasę czy narodowość wyraźnie widać to u Popovicia w scenie, w której Serb i Chorwat, weterani wojenni, niedawno stojący po przeciwnych stronach frontu, zostają połączeni wspólnym doświadczeniem wykluczenia. Žiljak zaś na wpół ironicznie sugeruje nawet zniesienie różnic międzygatunkowych, $\mathrm{w}$ finale powieści łącząc $\mathrm{w}$ dość specyficzną, niepozbawioną podtekstu seksualnego relację tytułowego irbisa i dwie kobiety. Taki binarny podział z pewnością nie pozostaje bez związku z opisywaną wcześniej schematycznością dystopii, jego celem staje się uwypuklenie prezentowanego obrazu, w którym nierówności ekonomiczne przekładają się na cały szereg praktyk pozwalających uzasadnić istniejący porządek społeczny. W utworach pojawiają się liczne sceny opisujące na przykład "czyszczenie” wybranych miejsc planety w celu zdobycia terenów pod uprawę, zabójstwa niewinnych dla rozrywki lub zysku, masowe śmierci z powodu chorób, które łatwo mogłyby zostać uleczone, czy eksperymentów przeprowadzanych na ",bezwartościowych" jednostkach. Nie budzą one jednak emocji wśród obywateli klasy uprzywilejowanej, owładniętych (prowadzącym do skrajnych usprawiedliwień moralnych) dyskursem kolonialnym, który Bogusław Bakuła definiuje jako:

nurt językowych, potocznych oraz instytucjonalnych (literackich, naukowych, politycznych) przekonań wskazujących na uzasadnione, we własnym dyskursie, poczucie wyższości oraz prawa do panowania nad innym strefami połączone z odmawianiem kolonizowanym zdolności do samoistnego bytu (niedojrzałość społeczno-polityczna, tzw. niehistoryczność, niski poziom cywilizacyjny), co w powieściach prowadzi w krańcowym efekcie do dehumanizacji (jak insekty, zwierzęta). Dyskurs kolonialny cechuje paternalizm, przekonanie o niepodważalnej dominacji własnego świata, dopuszczenie do głosu tzw. multikulturalizmu, czyli sterowanej wielokulturowości (Bakuła 2006: 17).

Jednocześnie większość uprzywilejowanych nie jest świadoma własnego podporządkowania i zniewolenia - posiadają oni podwójną tożsamość, stają się jednocześnie kolonizującymi i skolonizowanymi, „prześladującymi (w stosunku do 
autochtonów) i uciskającymi (w odniesieniu do centralnej kultury kolonizującej)" ${ }^{5}$ (Griffiths 175). Michel Foucault wyraża opinię, że współczesnym państwom Zachodu w niespotykanej dotąd mierze udało się doprowadzić do perfekcji i połączyć w jedno techniki polityczne oraz indywidualne: pisze o „politycznym «podwójnym szachu», który polega na równoczesnej indywidualizacji i totalizacji nowoczesnych struktur władzy" (Foucault 1998: 182). Techniki zewnętrznego nadzoru w opisanych powieściach nie wydają się przesadnie rozbudowane ani wymyślne - systemy kamer, które kontrolują przestrzeń publiczną, wszechobecne zakazy czy też mury i granice oddzielające od siebie państwa, kontynenty lub nawet osiedla, wszystko to uzasadnione chęcią ochrony obywateli i ich dóbr, praktycznie wszechobecne jest również w naszym świecie. Jeśli zatem szukać odpowiedzi na pytanie, co w równie dużym, jeśli nie $w$ większym stopniu umożliwia zachowanie porządku opisanego $\mathrm{w}$ dystopiach, trzeba zwrócić uwagę na wspomniane już techniki indywidualizacji lub autotechniki (Foucault nazywa je „technikami siebie”) - mechanizmy, dzięki którym człowiek zniewala się poprzez przyjęcie określonej tożsamości, przy okazji narzucając sobie normy, a co za tym idzie także ograniczenia zewnętrznej kontroli (Foucault 2009: 25).

Jednym z charakterystycznych przykładów ilustrujących te mechanizmy jest tzw. ewolucja antyemocjonalna opisana w powieści Planet Friedman. Mieszkańcy uprzywilejowanej strefy uważają, że emocje są nie tylko całkowicie niepotrzebne, ale również niebezpieczne - nikt jednak nie sprawuje szczegółowej kontroli nad tym, czy zasada o powstrzymywaniu się od nich jest faktycznie przestrzegana, jej złamanie przeważnie nie podlega też karze - tym niemniej dla mieszkających w zonie A jest ona oczywista i niezbędna do normalnego funkcjonowania. Odpowiedzialne są za to przede wszystkim techniki, które Foucault opisuje jako używane do ograniczania i represjonowania seksualności. Nie chodzi zatem o same ograniczenia albo też o skazywanie na zapomnienie poprzez zakaz mówienia o zjawisku. Istotne jest oplątanie emocji szeregiem dyskursów, nieustanne przywoływanie i poruszanie pozornie zakazanych tematów, zawsze jednak w zgodzie z narzuconą ideologią: „dyskursy nie mnożą się jednak poza władzą albo przeciwko niej, lecz w zasięgu tejże władzy i jako metoda jej sprawowania" (Foucault 2010: 31). Emocje obserwuje się i analizuje, mówi się o nich naukowo, tłumaczy się nimi problemy $\mathrm{w}$ adaptacji, uzasadnia popełnianie większości przestępstw. W ten sposób, przy pomocy dyskursu naukowego, medialnego przekazu i od dzieciństwa wpajanej członkom społeczności wiedzy o ryzyku i problemach związanych z emocjami, udaje się wyhodować ludzi, którzy samodzielnie i bez przymusu wyrzekają się swoich najbardziej naturalnych odczuć - dzieci wychowywane są w izolacji od rodziców, małżeństwo przypomina kontrakt, w powszechnym użyciu jest także pigułka PsychoR, reklamowana jako „wasz zaufany zabójca emocji” (Mlakić 47).

5 "Oppressor (with respect to the indigene) and oppressed (with respect to the metropolitan colonizing culture)". 
W tekstach wyraźna jest tęsknota za charakterystycznym dla współczesnych badań postkolonialnych mocnym, sprawczym podmiotem - podmiotem performatywnym, który mógłby przeciwstawić się represyjnym mechanizmom władzy. Jednocześnie jednak dominuje niewiara $w$ istnienie jakiejkolwiek alternatywy, pisarze zdają się przekuwać w literacką praktykę po wielekroć przywoływane stwierdzenie o końcu świata łatwiejszym do wyobrażenia niż koniec kapitalizmu' ${ }^{6}$ Ten problem zauważa Gajin, który twierdzi, że autorom chorwackich dystopii nie udaje się uniknąć pułapki percypowania kapitalizmu jako jedynego możliwego do pomyślenia systemu (Gajin 56). Podobnie Postnikov uważa, że krytycyzm powieści jest połowiczny, gdyż pomimo prezentacji społecznych antagonizmów w duchu rozważań o literaturze utopijnej spod znaku Suvina i Jamesona pozostaje on osadzony wewnątrz systemu, śledzi zaprogramowany ideologicznie konflikt jednostki z systemem i nie daje żadnej alternatywy dla kapitalizmu, a jedynie wizję jego reformy (Postnikov 2013).

Autorzy nieustannie podają w wątpliwość tezy Franza Fanona o oczyszczającej i uzdrawiającej sile przemocy, która prowadzi do wyzwolenia i „uczłowieczenia” podporządkowanego, skolonizowanego podmiotu (Fanon 1985) - Popović kwestionuje terrorystyczne działania Vrtlara, polegające na porwaniach, nierzadko torturach i morderstwach czołowych reprezentantów świata mocy i pieniądza, zaś Mlakić wprost ukazuje, jak rewolucja, której przewodzi okrutny i mściwy Blacktooth, zmienia dotychczasową hierarchię kapitału w piramidę strachu, nie dokonując przemian w zakresie metod działania czy położenia podporządkowanych mas, a jedynie wprowadzając jeszcze większy chaos oraz terror. Postnikov uważa to za słabość obu powieści, twierdząc, że ich potencjał w dużym stopniu wyczerpuje się $\mathrm{w}$ moralnych dylematach dotyczących uzasadnienia użycia przemocy do zburzenia niesprawiedliwego porządku społecznego (Postnikov 2013). Problem ten zostaje poruszony także w Irbisie, jednak tu przemoc ostatecznie okazuje się usprawiedliwiona potrzebą zmiany istniejącego stanu, tym niemniej (dosłowne) zburzenie starego świata $\mathrm{w}$ pieczołowicie zaplanowanym akcie terrorystycznym prowadzi do ironicznego finału, w którym odwróceniu ulega marzenie o utopii: do dyktatury "pozbawionych poczucia humoru” gigantycznych islamskich aniołów, które świetlistymi mieczami wprowadzają długo wyczekiwany pokój i sprawiedliwość.

Wizje zaprezentowane $\mathrm{w}$ większości chorwackich dystopii powstałych $\mathrm{w}$ ostatnim dziesięcioleciu odznaczają się dużym podobieństwem - tworzą konsekwentny i spójny wizerunek władzy oraz układu sił rządzących współczesnością. Rozważania i niepokoje twórców są $\mathrm{w}$ wielu miejscach zbieżne $\mathrm{z}$ refleksjami nad kondycją współczesności i problematyką biowładzy, którą podejmowali w swoich pracach

6 Cytuje je m.in. Frederick Jameson, nie podając jednak dokładnego źródła: „Someone once said that it is easier to imagine the end of the world than to imagine the end of capitalism" (Jameson 2003: 76). 
Foucault i Agamben. Chorwackie dystopie prezentują cywilizacje radykalnego neoliberalizmu, absolutnej dominacji wolnego rynku i globalnego bądź lokalnego kapitalizmu, jednocześnie jednak stają się uniwersalnymi opowieściami o podporządkowaniu.

\section{BIBLIOGRAFIA}

Agamben, Giorgio. Homo sacer. Suwerenna władza i nagie życie. Przeł. Mateusz Salwa. Warszawa: Prószyński i S-ka, 2008.

Bagić, Krešimir. „Od kritičkog mimetizma do interdiskurzivnosti”. Sarajevske sveske 14 (2007). S. 176-198. Bagić, Krešimir. Uvod u suvremenu hrvatsku književnost 1970-2010. Zagreb: Školska knjiga, 2016.

Bakuła, Bogusław. „Kolonialne i postkolonialne aspekty polskiego dyskursu kresoznawczego (zarys problematyki)". Teksty Drugie 6 (2006). S. 11-33.

Brešan, Ivo. „Ako je masturbacija glavni problem, onda k vragu i cijela zemlja”. Novosti 686 (2013). Web. 09.09.2016. <http://www.novossti.com/2013/02/ako-je-masturbacijaglavni-problem-onda-k-vragu-i-cijela-zemlja/>

Domańska, Ewa. „Badania postkolonialne”. Gandhi, Leela. Teoria postkolonialna: wprowadzenie krytyczne. Przeł. Jacek Serwański. Poznań: Wydawnictwo Poznańskie, 2008. S. 157-164.

Fanon, Frantz. Wyklęty lud ziemi. Przeł. Hanna Tygielska. Warszawa: Państwowy Instytut Wydawniczy, 1985.

Foucault, Michel. Nadzorować i karać. Narodziny więzienia. Przeł. Tadeusz Komendant. Warszawa: Wydawnictwo Aletheia, 2009.

Foucault, Michel. Podmiot i władza. Przeł. Jacek Zychowicz. Lewa Nogą 9 (1998). S. 174-178.

Foucault, Michel. Wola wiedzy. Przeł. Bogdan Banasiak, Krzysztof Matuszewski. Historia seksualności. Gdańsk: słowo/obraz terytoria, 2010.

Gajin, Igor. „Trend distopijskog u suvremenoj hrvatskoj prozi”. Anafora 1 (2015). S. 41-58.

Griffiths, Gareth. „The Post-colonial Project: Critical Approaches and Problems”. New National and Postcolonial Literatures: An Introduction. Red. B. King. Oxford: Clarendon Press, 1996. S. 164-177.

Jameson, Frederick. Archeologie przyszłości. Pragnienie zwane utopia i inne fantazje naukowe. Przeł. Maciej Płaza, Małgorzata Frankiewicz, Andrzej Miszk. Kraków: Wydawnictwo Uniwersytetu Jagiellońskiego, 2011.

Jameson, Frederick, „Future City”. New Left Review 21 (2003). S. 65-79.

Jarzębski, Jerzy. „,Realizm podszyty fantastyką". Teksty Drugie 6 (2008). S. 44-53.

Juszczyk, Andrzej. Stary wspaniaty świat. O utopiach pozytywnych i negatywnych. Kraków: Wydawnictwo Uniwersytetu Jagiellońskiego, 2014.

Mlakić, Josip. Planet Friedman. Zagreb: Fraktura, 2012.

Pavičić, Jurica. „Prošlo je vrijeme Sumatra i Javi”. Sarajevske sveske 5 (2004). S. 125-136.

Pogačnik, Jagna. „Novi hrvatski roman”. Sarajevske sveske 13 (2006). S. 75-96.

Pogačnik, Jagna. „Gdje je nestala utopija?”. Kolo 4 (2004). S. 179-188.

Popović, Edo. Lomljenje vjetra. Zagreb: OceanMore, 2011. 
Postnikov, Boris. „Imaginiranje sutrašnjice bez budućnosti”. Le Monde diplomatique XI (2013).

Web. 10.10.2016. <http://lemondediplomatique.hr/imaginiranje-sutrasnjice-bez-buducnosti/>

Sargent, Lyman Tower. „The Three Faces of Utopianism Revisited”. Utopian Studies 5 (1994). S. 1-37.

Szacki, Jerzy. Spotkania z utopia. Warszawa: Sic!, 2000.

Spivak, Gayatri Chakravorty. „Czy podporządkowani Inni mogą przemówić?”. Przeł. Ewa Majewska. Krytyka Polityczna 24-25 (2011). S. 196-239.

Suvin, Darko. „Theses on dystopia 2001”. Dark Horizons: Science Fiction and the Dystopian Imagination.

Red. R. Baccolini, T. Moylan. New York and London: Routledge, 2003. S. 187-201.

Zgorzelski, Andrzej. „SF jako pojęcie systemu historycznoliterackiego”. System i funkcja. Ustalenia metodologiczne i propozycje teoretycznoliterackie. Gdańsk: Wydawnictwo Gdańskie, 1999. S. 89-108.

Žiljak, Aleksandar. Irbis. Zagreb: Zagrebačka naklada, 2012. 